\title{
Colloquium on Youth Day 16 June 2017: The Commission of Faith and Order of the World Council of Churches in association with the Faculty of Theology of the University of Pretoria and its centennial celebration in 2017
}

\section{Authors:}

Andries G. Van Aarde ${ }^{1}$

L. Wiseman Nkuhlu ${ }^{1}$ Johan Buitendag ${ }^{1}$ (D)

Olav F. Tveit ${ }^{2}$ Jerry Pillay ${ }^{1,3}$ (D)

Mary Anne Plaatjies van Huffel ${ }^{4,5}$ (1)

Gustav Claassen ${ }^{6}$

André Ungerer ${ }^{1,7}$

\section{Affiliations:}

${ }^{1}$ Faculty of Theology,

University of Pretoria,

South Africa

${ }^{2}$ World Council of Churches, Switzerland

${ }^{3}$ World Communion of Reformed Churches,

South Africa

${ }^{4}$ World Council of Churches Africa; Uniting Reformed Church in Southern Africa, South Africa

${ }^{5}$ Department of Church History and Church Polity, Stellenbosch University, South Africa

${ }^{6}$ Dutch Reformed Church

${ }^{7}$ Netherdutch Reformed Church of Africa, South Africa

Research Project Registration: Project Leader: A.G. van Aarde Project Number: 2334682

Read online:
This article represents the contributions of ecclesiastical and academic office bearers participating in the centennial celebration of the Faculty of Theology of the University of Pretoria on Youth Day 16 June 2017, in collaboration with the Faith and Order Commission of the World Council of Churches. This Youth Day commemoration showcases the profound way of transformation at the University of Pretoria and, in particular, its theological faculty in democratic South Africa since 1994. It presents a truly historic event, highlighting a global participation of specifically the Reformed churches in South Africa after a period of ecumenical isolation because of a formerly endorsement of apartheid, nowadays confessed as a theological and humanitarian heresy.

\section{A.G. van Aarde - what kind of community do we seek?}

It is my honour to welcome each and every one of you to this colloquium on Youth Day 16 June 2017, which is organised by the Commission of Faith and Order of the World Council of Churches (WCC) in association with the Faculty of Theology of the University of Pretoria, as part of its centennial celebration in 2017, as well as in association with the Dutch Reformed Church (DRC), readmitted as a full member of the WCC. Our sincere hope is that this historic event may be regarded as part of the restitution for the failure of the Cottesloe Consultation in December 1960 in the aftermath of the Sharpeville massacre in March 1960 and the consequences of the Soweto Youth Uprising in June 1976.

My word of welcoming is addressed to particularly:

- Professor L. Wiseman Nkuhlu, Chancellor of the University of Pretoria.

- Professor Johan Buitendag, Dean of the Faculty of Theology.

- The Director of the Commission of Faith and Order of the WCC, the Rev. Dr Odair Pedroso Matteus.

- Rev. Dr Susan Durber of the United Reformed Church in the United Kingdom, Moderator of the Commission of Faith and Order of the WCC and co-moderator of today's colloquium.

- The President of the World Communion of Reformed Churches (WCRC), Professor Jerry Pillay, Head of the Department of Church History and Polity at the Faculty of Theology of the University of Pretoria.

- The WCC President for Africa, Professor Mary Anne Plaatjies van Huffel, Moderator of the Uniting Reformed Church in Southern Africa and Professor of Church History and Church Polity at the Stellenbosch University.

- The General Secretary of the South African Council of Churches (SACC), Bishop M. Malusi Mpumlwana.

Description: 'Biblical Theology and Hermeneutics', directed by Prof. Dr Andries G. van Aarde, Post Retirement Professor in the Dean's Office of the Faculty of Theology of the University of Pretoria. This article represents the 'Welcoming word', presented at Youth Day 16 June 2017 in the Senate Hall of the University of Pretoria as part of the Commission of Faith and Order of the World Council of Churches June 2017 in the Senate Hall of the University of Pretoria as part of the Commission of Faith and Order of the World
collaborating with the Faculty of Theology of the University of Pretoria during its centennial celebration in 2017. Corresponding author: Andries van Aarde, andries.vanaarde@aosis.co.za

Dates: Received: 27 July 2017 | Accepted: 31 July 2017 | Published: 30 Nov. 2017

How to cite this article: Van Aarde, A.G., Wiseman Nkuhlu, L., Buitendag, J., et al., 2017, 'Colloquium on Youth Day 16 June 2017 : The Commission of Faith and Order of the World Council of Churches in association with the Faculty of Theology of the University of Pretoria and its centennial celebration in 2017', HTS Teologiese Studies/Theological Studies 73(1), a4749. https://doi.org/10.4102/hts.v73i1.4749 Copyright: @ 2017 . The Authors. Licensee: AOSIS. This work is licensed under the Creative Commons Attribution License. 
- WCC Programme Executive for Church and Ecumenical Relations, Archpriest Dr Habil Daniel Buda.

- The General Secretary of the DRC, Dr Gustav Claassen.

- The Moderator of the Netherdutch Reformed Church of Africa (NRCA), Dr André Ungerer, Head of the Reformed Theological College at the University of Pretoria.

- The moderating team of today's colloquium: Professor Nelus Niemandt, Emeritus Moderator Dutch Reformed Church and Head of the Department of Science of Religion and Missiology at the Faculty of Theology of the University of Pretoria; and Father Professor William Henn, the Robert Bellarmine Professor of Ecclesiology and Ecumenism at the Pontifical Gregorian University in Rome, and representing the Roman Catholic Church as a member of the Standing Commission of the WCC Commission on Faith and Order.

- The keynote speakers: Rev. Yolanda Pantou of the Indonesia Christian Church; and Professor Reginald W. Nel, Professor of Missiology at the University of South Africa.

- Participants and delegates of the Commission of Faith and Order of the WCC.

- Members and leaders of other church members of the WCC.

- Students and attendees of our colloquium.

Please accept apology for the absence of the Vice Chancellor of the University of Pretoria, Professor Cheryl de la Rey, the General Secretary of the WCC, Rev. Dr Olav Fykse Tveit and the Moderator of the DRC, Rev. Dr Nelis Janse van Rensburg.

The main objective of the Cottesloe Consultation in December 1960 was a meeting of the delegates from the member churches in South Africa of the WCC, together with representatives of the World Council itself, to seek under divine guidance to understand the complex problems of human relationships in this country, and to consult with one another on our common task and responsibility in the light of the divine wisdom in the Word of God. The resolutions reached are, among others, the statement that no one who believes in Jesus Christ may be excluded from any church on the grounds of her and his colour or race. The spiritual unity among humankind who are in Christ must find visible expression in acts of common worship and witness, and in fellowship and consultation on matters of common concern.

The church of Jesus Christ, by its nature and calling, is deeply concerned with the welfare of all people, both as individuals and as members of social groups. It is called to minister to human need in whatever circumstances and forms it appears, and to insist that all be done with justice. In its social witness, the church must take cognisance of all attitudes, forces, policies and laws which affect the life of people. The church must proclaim that the final criterion of all social and political actions is the principle of God's wisdom regarding the realisation of all human beings of a life worthy of their God-given vocation.
The then South African Prime Minister Dr H.F. Verwoerd, together with some Afrikaner church leaders, was instrumental in the Cottesloe Consultation not succeeding in realisation of its goals. Soweto June 1976 was truly a youth revolution that illustrated in a concrete way that apartheid can in no way be regarded as justifiable. It is a violent, oppressive and racist ideology. During the past 2 years, we have experienced on university campuses in South Africa as well as here at the University of Pretoria - that the children picked up on their parents' pain and anger expressed in the 1960s and the 1970s (see Du Preez 2016:22-23; my paraphrasing translation from original Afrikaans).

This colloquium is an attempt to reflect on that pain and on future hope granted by the Spirit of God. In our churches, we have not done enough to create a true restitution, acknowledging the complexities of being a truly united learning faith community.

The Vancouver Assembly in 1983 was the first WCC assembly to give focused attention to the issue of youth and especially education in church and society. In 1983, six aspects constituted the content of the then colloquium, namely (see WCC [1983] 2016:378-380):

- family education

- liturgical education

- congregational education

- formal education

- theological education

- development education.

The result of the colloquium was formulated as follows:

We have come from different backgrounds with a variety of experiences, hopes and frustrations in learning. We were prepared to learn from each other to find out how the church may become a learning community.

To me, it means listening to the youth as a gateway to the future - the motto of the centennial celebration of the Faculty of Theology at the University of Pretoria, South Africa's oldest theological faculty (cf. Van Aarde 2017).

The report of the 1983 colloquium continues: 'We discovered various hindrances on the way to becoming a learning community':

- Language limitations hindered full communication among us.

- Different and even conflicting cultural, social and economic backgrounds which make it difficult to encounter each other in a trusting way.

- Different theological approaches that sometimes led to misunderstandings and conflicts.

We discovered painfully that learning in community requires much time, patience and readiness to listen to one another'.

My hope is that today's colloquium, on Youth Day 16 June 2017, here in the Senate Hall of the University of Pretoria, will 
contribute to the realisation of the desire to listen to one another and to learn from one another with regard to the engagement of God's people with the youth of today and tomorrow.

However, the colloquium of 1983 stated that reflection on learning and education concerns more than the youth. It requires:

- Through the willingness to assist one another, we can overcome language barriers.

- Through the readiness to share frankly our different positions, concepts and experiences, we can create openness for trust and thus learn from one another.

- The fellowship among churches is both a challenge and enrichment, and is therefore an indispensable prerequisite for learning in community.

The question in 1983 was and remains today the same:

‘Which kind of community do we seek?' (WCC [1983] 2016:378-380)

The experiences of three decades ago helped the WCC in 1983 to discover and reflect on future goals of learning in community. These goals are still our goals today, namely:

- To help one another to believe in Jesus Christ as the source of life and to grow in faith as Christian persons.

- To discover together that God has given us one world.

- To participate in the struggle for global justice and peace.

- To participate in communities of prophetic witness.

- To relate our global struggles and global perspectives to regional and local experiences.

In present-day South African educational context, the lastmentioned goal is related to what is referred to as 'decolonialisation'.

Finally, with regard to theological education, the colloquium of 1983 stated, and I paraphrase as follows:

Theological education is a process of learning that belongs to the whole people of God. It is more than the development of ministerial skills or the gaining of theological knowledge by individuals. Theological education involves the transformation of concepts and people for faithful leadership. In this context, theology is understood as a reflection on faith in God as human response to the given truth. This reflection includes issues of lifestyle and decisionmaking, equipping people for action in society, as well as the relationship with God and persons. Theology and theological education are always to be understood in the cultural, social, spiritual, political and other contextual realities of society. Theological education, therefore, is called to address the particular problems and opportunities of local and regional community, against the background of a wider global awareness, including our concerns and challenges regarding climate change causing a massive environmental crisis that is threatening God's creation.
In addition, theological education must deal with the relationships between action and reflection, experience and tradition, the personal and the collective and the local and the global. Theological learning includes spiritual development and ecumenical understanding towards the goal of a new human community. However, there is a need for fresh curricula and appropriate criteria for the evaluation of learners, which should be consistent with the wider and fuller participation in human community, the oikoumene.

It will be my greatest joy if this colloquium could contribute to the realisation of these objectives of the WCC formulated in 1983. Furthermore, I hope that this colloquium will create the dynamics for learning and education to become a much more focused item on the agenda of the Commission of Faith and Order and in the assemblies of the WCC. Lastly, my hope is that the ECHOS commission of the Faith and Order Commission, reflecting and studying youth engagement in the ecumenical world, will help Pretoria and South Africa to learn from your global experiences in order for restitution to take place for the problems of the 1960s, 1970s and today. We should also turn to the youth to teach us by making them in future integral to our reflection, so that we, by the grace of God, would have a promiseful future in South Africa and worldwide.

\section{Wiseman Nkuhlu - colloquium on Youth Day (16 June 2017) in association with the centenary celebrations of the Faculty of Theology: Gateway to ..., Senate Hall, University of Pretoria}

As Chancellor of the University of Pretoria, it is my honour and privilege to welcome you all to this historic event. In particular, I extend a hearty welcome to our guests. As the University community, we are pleased to host the representatives of the WCC, the WCRC, Christian religious leaders from friendly countries across the globe, representatives of the SACC and leaders of churches that have been associated with the Faculty of Theology of the University of Pretoria throughout its history.

It is day of great significance to the University of Pretoria and the Faculty of Theology in particular. The Faculty is celebrating its centenary this year and has decided to hold this colloquium on June 16th, the day that young black students rebelled against apartheid and imposition of Afrikaans as a language of instruction.

Sixteen June 1976 marked the turning point in the struggle against racism and oppression in our country. From that day onwards, the internal struggle intensified. Black people were no longer afraid of the military might of the Afrikaner establishment.

More pertinent for this occasion, the Christian community all over the world condemned racism and apartheid as evil and unchristian. The SACC led the charge internally. 
However, the oldest Faculty of Theology in the country and the thought leaders of its most influential churches, the DRC and the NRCA, became themselves entangled in the politics and ideology of bigotry and racist supremacy and as a consequence alienated themselves from the World Community of Churches. In his contribution to the deliberations of this colloquium, Dr Kobus Gerber makes the following pertinent observation 'Some of the most important prophets for apartheid and prophets against apartheid came out of these corridors' (meaning the Faculty of Theology at the University of Pretoria). He goes on to say 'these corridors were the safe spaces where they interacted and struggled theologically and where sound theology in the long run triumphed' (unpublished paper, presented at the Conference Gateway to the future from a deconstructed past', 05-06 April 2017, University of Pretoria).

It is that triumph that we are celebrating today on 16 June 2017. Sound theology is victorious over bad and unsound theology. The DRC and the NRCA have been reconciled to the World Community of Churches. Sacrifices by Adrianus Van Selms, Albert Geyser, Beyers Naudé and Allan Boesak are vindicated.

We commend the Dean of the Faculty Prof. Johan Buitendag and his colleagues for repositioning the faculty and rebuilding its international standing as a centre of academic excellence and thought leadership. We encourage them to take their rightful place and to be active members in the World Community of Churches and contribute to the processes of reconciliation, healing and nation building in our country.

As the leadership of the University of Pretoria, we acknowledge our past. We know that our university was part and parcel of a racist South Africa that inflicted pain and suffering on black people. We also know that it takes time and determination to transform an organisation with that kind of legacy. However, we are determined to succeed. Our mission is to be a leading research university in Africa, recognised internationally for its quality, relevance and impact and also for developing people and creating knowledge and making a difference locally and globally.

I am glad to affirm that we are making commendable progress on transformation. Over $60 \%$ of our students are black students, our student pass rate is over $90 \%$ and we are a leading university in the production of high-level skills, engineering and veterinary science in particular, and our contribution to the production of new and relevant knowledge through research is increasing. We are making a significant contribution in building and shaping a South Africa of President Nelson Mandela's dreams.

The Faculty of Theology has embraced and internalised the new vision and is engaged together with other stakeholders in a search for a new identity and purpose that will unite and energise us as South Africans.
The leadership of the WCC, WCRC and the SACC is commemorating 16 June with the Faculty of Theology here at the University of Pretoria. A miracle no one could have imagined possible 41 years ago. Yes, nothing is impossible as long as men and women of goodwill do not give up. Good will triumph over evil. Yes, in South Africa too, we experienced victory over evil in 1994 and we are going to experience it again over state capture and corruption.

In conclusion, I congratulate the Faculty of Theology once more on its centenary and wish all the participants a successful colloquium and a memorable experience at the University of Pretoria.

\section{J. Buitendag - 'Listening to the youth as gateway to the future'}

It is with a profound sense of joy that I welcome you all here today on behalf of the Faculty of Theology at the University of Pretoria. It is 57 years since the last visit of a WCC delegation of this sort. In the intervening period, so much has changed globally and especially here in South Africa. The reason that inspired a consultation in 1960 - the institutionalised racism of apartheid - has gone. I want to congratulate the moderating team for choosing such an outstanding topic: 'Listening to the youth as gateway to the future', based on Romans 10:14-15 and the WCC's youth programmes.

This evidently dovetails with the theme of the Centenary of open gates.

This university and its Faculty of Theology have also changed during the past 100 years. From a two church, two-section faculty, all white and male dominated, we now boast of our multichurch representation in a single faculty, with many female staff members and over $50 \%$ black students, and a staff and curriculum which are continually undergoing transformation. Long gone are the days when we provided the theological justification of apartheid; we also provided some of its sternest critics.

The faculty's vision and mission epitomise what we regard as important in shaping our future and determining our strategy:

Vision: To be a faculty recognised for its creative engagement with life-giving theology and religious insight, of service to academia, church and community.

Mission: To achieve this, we commit ourselves to:

- providing relevant theological and religious education

- $\quad$ nurturing transformative leaders

- undertaking quality research

- $\quad$ promoting justice, peace, the integrity of creation and a reconciling diversity

- $\quad$ engaging with people on the margins of society.

The deconstruction of our past is a key theme in our centenary year as we celebrate our transformed existence and orientation towards a renewed future with our centenary 
slogan 'Gateway to ...' a future marked by unity in radicalreconciled diversity. This was what the majority of South Africans had wanted for many years, not least as evidenced in 1960.

We meet on a public holiday now deeply rooted in our nation's history and corporate memory, June 16, Youth Day, is not a day of celebration but a day of commemoration.

No one should underestimate the importance and value of today's historic event. Surely, we will be hearing this afternoon the journey of the Afrikaans churches' history with the ecumenical world and the diabolical connection these churches had with the political powers of the day. The semiotic meaning of the words Sharpeville and Soweto will never be what they had been prior to 1960 and 1976 .

At a press conference held on Saturday 19 March 1960, Pan Africanist Congress (PAC) President Robert Sobukwe announced that the PAC was going to embark on an anti-pass campaign on Monday, 21 March in Sharpeville. At the press conference, Sobukwe emphasised that the campaign should be conducted in a spirit of absolute nonviolence and that the PAC saw it as the first step in black people's bid for total independence and freedom. Sobukwe subsequently announced that:

African people have entrusted their whole future to us. And we have sworn that we are leading them, not to death, but to life abundant. My instructions, therefore, are that our people must be taught now and continuously that in this campaign we are going to observe absolute non-violence. (Isaacs 2016)

This unfortunately ended up in a catastrophe. According to the police, protesters began to stone them and, without any warning, one of the police officers on the top of an armoured car panicked and opened fire. His colleagues followed and opened fire. The firing lasted for approximately $2 \mathrm{~min}$, leaving 69 people dead and, according to the official inquest, 180 people seriously wounded.

When the language of Afrikaans alongside English was made compulsory as a medium of instruction in schools in 1974, black students began mobilising themselves. In Soweto on 16 June 1976 between 3000 and 10000 students mobilised by the South African Students Movement's Action Committee supported by the Black Consciousness Movement (BCM) marched peacefully to demonstrate and protest against the government's directive.

The uprising took place at a time when liberation movements were banned throughout the country and South Africa was in the grip of apartheid. The protest started peacefully in Soweto but it turned violent when the police opened fire on unarmed students. By the third day, the unrest had gained momentum and spread to townships around Soweto and other parts of the country. The class of 1976 bravely took to the streets and overturned the whole notion that workers were the only essential force to challenge the apartheid regime. Indeed, they succeeded where their parents had failed.
Student organisations directed the energy and anger of the youth towards political resistance.

And still today, it is students who are providing leadership to resistance in the face of the government's inability to meet its responsibilities as outlined in the Freedom Charter. We can repeat oft-quoted words regarding their contribution to our national life:

Never in the field of human conflict was so much owed by so many to so few.

We are grateful that you have chosen to come to South Africa and that we can count you as participants in our centenary celebrations in a rapidly and ever-changing process of transformation. We wish you well in your deliberations for the sake of the youth of our nation and all nations and for the sake of Christ's coming kingdom:

Youth of June 16

This was the youth with a dream and a mission

Driven by a vision and a passion and

Inspiration drawn from the harshest of all situations

Their burning desire for democracy and recognition

Drove them to take action and stand for what they believed in.

These were role models and indeed the greatest of all leaders,

True leaders who held their visions of the future at the centre of themselves

And role models who believed that their actions would create the future

A future for them, a future for you and I

At least today and now you and I can testify on their behalf. (Gwala, n.d.)

Where does this bring us now? It is all about Life in its Fullness and education that can bring that about.

The language policy of the Apartheid regime was counterproductive. It incited the students to move from apartheid in education to no education before liberation and 'No education before liberation' became their slogan.

Athol Fugard, the South African playwright, communicated the message of not either/or but both and forcefully in his drama of 1989, My Children! My Africa! Mere words devoid of actions or feelings are empty rhetoric; mere actions devoid of word or reasoned thought are mayhem. Just before his murder, Mr M, the well-respected black teacher in the drama, stands in his classroom holding his dictionary in one hand and a rock that had been thrown through the classroom's window, in the other hand. Each symbol by itself represents a worthless approach to problem solving and more particularly to South African problem solving. Together, the two, action and words, can educate and spur reform.

Yet, there is a distinction between a dictionary and a stone, although they weigh about the same. The dictionary in $\mathrm{Mr}$ M's hands contains 60000 words in the English language, 
whereas the stone expresses just one. A rock is only a rock and a dictionary carries the force of the entire English language. As Fugard rightly says, stones cannot get into an armed vehicle, but words can. By the play's close, we understand $\mathrm{Mr} \mathrm{M}$ that sometimes words speak louder than actions.

I have expressed more than once my conviction that the Faculty of Theology at the University of Pretoria has played a decisive role in this country in bringing churches together. I am even prepared to say the Spirit is using this Faculty par excellence, to achieve this. The DRC (Dutch Reformed Church) and NRCA (Netherdutch Reformed Church of Africa) have never been so close to another as now and accept one another's ministers without a colloquium; the DRC and URCSA (Uniting Reformed Church in Southern Africa) train their ministers at the same faculty and the PRCSA (Uniting Presbyterian Church in Southern Africa) and the EPCSA (Evangelical Presbyterian Church in South Africa) are trained together, and could probably share a chair in the Faculty.

No other faculty in this country can claim that it has had so many moderators on its staff. All four our partner churches had at least two moderators employed by the University. No wonder that the churches are becoming so close.

Our Centenary Celebration's last event is the celebration of 500 years of Reformation and that will happen in the Aula by means of an ecumenical service with the theme: 'Let us be one'.

The Faculty has its mission to practise theology in such a way that the love of God reaches all. The vista that has been opened by the Centenary Celebration and its theme is succinctly captured in Ezekiel 47. From the temple, there will be a flowing stream, which increases in volume and healing effect: the stream will make the water of the Dead Sea fresh, and wherever it flows, it will bring life (verse 9).

Socrates said, 'The secret of change is to focus all of your energy, not on fighting the old, but on building the new'. It is important not only to interpret the past, but also to come to terms with it and to take up the challenges of the future directed by a clear vision and based on solid values.

Kofi Annan, former Secretary General of the United Nations, strongly promoted the importance of universities for development in Africa:

The university must become a primary tool for Africa's development in the new century. Universities can help develop African expertise; they can enhance the analysis of African problems; strengthen domestic institutions; serve as a model environment for the practice of good governance, conflict resolution and respect for human rights, and enable African academics to play an active part in the global community of scholars (Corcoran \& Osano 2009:147).

This means that universities have to become agents of change and the critical source of equalisation of chances and democratisation of society by making possible equal opportunities for people'. This is particularly true for a university in Africa.

It is my privilege now to express a formal word of gratitude to each one of you. We are honoured to have had in our midst so many dignitaries. Thank you to everyone who has brought messages of greetings.

In particular, I would like to thank:

- The Moderating Team.

- Prof. Wiseman Nkuhlu, the Chancellor of the University of Pretoria.

- Prof. Andries van Aarde for his dedicated input and energy.

- Dr Susan Durber, Moderator of the Faith and Order Commission.

- The two keynote speakers, Rev. Yolanda Pantou and Prof. Reginald Nel.

- And finally yet importantly, Archpriest Prof. Daniel Buda, WCC Programme Executive for Church and Ecumenical Relations.

Allow me to acknowledge the financial sponsorship of the DRC, the Motsepe Foundation and the WCC.

I am willing to say with confidence, that this event today has indeed contributed much towards restitution for the failure of the Cottesloe Consultation.

I congratulate the DRC with their readmitted membership of the WCC, I commend the Executive of the Faith and Order Commission for opening the gates and finally yet importantly, I call upon the Netherdutch Church of Africa to pursue the appeal to become one with zest.

\section{Olav Fykse Tveit - 'The Lord has done great things for us; we are glad' (Ps 126:3)}

Geneva, 13 June 2017:

- Respected Prof. L. W. Nkuhlu, Chancellor of the University of Pretoria,

- Respected Prof. Johan Buitendag, Dean of the Theological Faculty,

- Respected Dr Gustav Claassen, General Secretary of the DRC,

- Honourable representatives of the leadership of Churches, Councils and Fellowships,

- Honourable Professors,

- Honourable members of the Commission on Faith and Order,

- Dear students,

- Dear brothers and sisters in Christ:

'The Lord has done great things for us; we are glad'. (Ps 126:3)

I would like to open my address with these words of the Psalms, which express both God's providence and the joy of 
the people of God for being part of it. The reason for choosing this biblical quotation here is that its words fit well with the context of this gathering. Indeed, our Lord has done great things for us, so that this colloquium on Youth Day can be held at the Theological Faculty of Pretoria University with broad ecumenical participation and so that the meeting of the Commission on Faith and Order can take place in South Africa.

It is also a great thing indeed that apartheid as a legal system belongs definitely to the past and that the chief constituencies of South African society, including churches, religious communities and universities, are involved in healing its remaining wounds and in constructing a future of justice and peace for everyone in South Africa despite the many challenges the country is facing today. It is a great thing indeed that the DRC has been readmitted to the fellowship of the WCC after a long and careful process and is now hosting the first meeting of the Faith and Order Commission in South Africa. It is a great thing that the Theological Faculty of Pretoria University, while celebrating its centenary, invited all of us to reflect in this colloquium on the role of youth in churches, societies and in the ecumenical movement using as one of the starting points, the consequences of the Soweto Youth uprising of June 1976. For all these, we can indeed repeat with the psalmist:

'The Lord has done great things for us; we are glad.'

We also know that all these great achievements were possible because people, churches and ecumenical organisations chose, in difficult times, to stand against injustice and discrimination. They chose to be tools and prophetic voices of the Lord, standing for those discriminated against, marginalised and undermined. As we look back at the Programme to Combat Racism, which was established by the central committee of the WCC in 1969, and on its achievements in South Africa and in other parts of the world, we can all agree that it was an expression of the providence of God and that we were part of it.

While rejoicing in the great things that the Lord has been done for us and through us, we must not forget that our voices and action are needed in many parts of the world. Racism constantly takes new forms and shapes and creates victims in different parts of the world, sometimes in places we expect the least. Therefore, while we give thanks to God for the great things done for and with us and we are glad for them, we should also be awake and alert in order to serve justice and peace in the world. Focusing on the young generation, seeking to explore and empower their potential, letting them learn from both the mistakes and achievements of the past, bringing generations together for the sake of justice and peace - these are all facets of a pilgrimage that we all should promote more and more.

I wish you all a fruitful colloquium and to the Faith and Order commissioners a good and inspiring commission meeting! Yours in our Lord.

\section{Jerry Pillay - greetings and messages from the World Communion of Reformed Churches}

It is a joy and privilege to be among you today and to bring you the greetings of the WCRC. The staff in our office in Hannover, Germany, and over 80 million Reformed Christians in 109 countries in the world from our 230 member churches join me in bringing greetings and best wishes to you for this very historic meeting.

We like to express our thanks and appreciation to the WCC Faith and Order Commission for agreeing to meet here hosted by the DRC. This is indeed a big event for the DRC given the history of the past. We know that after the Cottlesloe Conference that was convened by the WCC in 1960 to discuss racial segregation in South Africa after the Sharpeville massacre, the DRC later chose to withdraw from the WCC. The DRC was readmitted to the WCC in 2016 for which we give thanks.

The DRC underwent a similar process in the WCRC. In 1982, the General Council of the then World Alliance of Reformed Churches suspended the DRC declaring apartheid as a status confessionis, a belief that the DRC theological justification of apartheid was a heresy. On 13 October, the DRC rejoined the WARC after their general council renounced apartheid. Since then the DRC has continued to play a significant role in the life and work of the WCRC, which we greatly appreciate.

This year we celebrate 500 years of the Martin Luther Reformation. Five-hundred years ago, Reformers were concerned about the state of the church. And now 500 years later, we sense an even greater need for renewal and transformation of both church and society. Thus, the WCRC is holding its next General Council at the end of this month under the theme: 'Living God, renew and transform us'.

The WCRC has identified five key areas in which we are called to exercise the courage to seek renewal and transformation.

\section{Renewal in our commitment to God's mission}

Our task in the world as Christians and as church is to proclaim Christ to the world. The church as a community does not exist for itself. It has received a commission; it is sent into the world to proclaim and praise God. Christians are called to have the courage to embody and proclaim Christ in holistic mission in the world.

\section{Renewal in our call to communion}

The WCRC stated clearly at its Uniting General Council in Grand Rapids, in 2010, that it is called to communion and committed to justice. We believe that unity is a gift from God; therefore, we need to have the courage to work at the issues that brings disunity, both within our communion and outside of it. We are thus seeking to engage on matters that creates 
separation and divisions such as the ordination of women and human sexuality within the WCRC family.

\section{Renewal in our commitment to justice and peace}

The struggle for justice is crucial; it is part and parcel to the Christian Gospel. In fact, it is the declaration of the Lordship of Jesus Christ. Whenever Christians speak out and act against injustice, inequality and the dehumanisation of the human being, they serve as the ambassadors and servants of Christ. The Accra Confession clearly establishes the WCRC commitment to justice in three particular areas: economic justice, gender justice and ecological justice.

\section{Theological renewal and transformation}

The WCRC has sensed the need for theological renewal and transformation in keeping with one of our essential beliefs that 'the reformed church is always reforming'. We note that for far too long we have engaged theological formation from Western perspectives, with the shift of Christianity to the Global South, we need to ask how we can embrace theological insights and stimulation from new centres. Noteworthy is our approach in the Global Institute of Theology to allow young theologians to both challenge and lead us in theological engagement.

\section{Renewal in our commitment to ecumenical engagement}

It is often said that to be reformed is to be ecumenical. Reformed churches have strengthened ecumenical movements in their participation, desire and efforts for unity among churches. Added to this is the knowledge that we cannot tackle all the problems in the world by ourselves. The WCRC, in this year of the 500th Reformation, renews its commitment to work with other ecumenical partners, churches, interreligious organisations and others to create a better life for all.

\section{Conclusion}

The 16th century Reformation was aimed at getting the teachings of the church and the life of the people in line with the Word of God. It was an era of great change as it transformed both church and society. In light of the contextual realities in the world today and the shift of Christianity to the Global South, the WCRC is praying and working for renewal in Reformed theology and spirituality. We join the 2017 celebrations with the hope and joyful anticipation of God's Spirit continuing to transform both the church and the world, and our personal and communal prayer is: 'Living God, Renew and Transform Us'.

A world in crisis is crying out for justice and peace. It is imperative that Christians across the globe join hands and effort in working towards the 'fullness of life' for all people on earth. As the Faith and Order Commission continues its work and foster church unity, it would be important for it to draw from the Barmen Declaration, Belhar Confession and the Accra Confession. May I conclude by encouraging you with the words of the Apostle Paul in Philippians 3:12-14:

Not that I have already obtained all this, or have already made perfect, but I press on to take hold of that which Christ Jesus took hold of me. Sisters and brothers, I do not consider myself yet to have taken hold of it. But one thing I do: Forgetting what is behind and straining toward what is ahead, I press on toward the goal to win the prize for which God has called me heavenward in Christ Jesus.

The task of church unity and witness in the world is not easy. My prayer is that you would not give up but as the Apostle Paul says 'keep pressing on'. I hope that the Faith and Order Commission meeting here in these days would help and encourage all of us in 'pressing on' with the things that bring Glory to God and abundance of life to all. Thank you for the opportunity to be with you today. God Bless!

\section{Mary Anne Plaatjies van Huffel - Gateway to the ...}

Dear Prof. Dr Andries Van Aarde, Rev. Dr Susan Durber, Prof. Dr Nelus Niemandt and Prof. Dr William Henn, thanks for invitation to be part of the WCC Faith and Order Commission Meeting and Youth Day Symposium. Much appreciated. A special word of thanks to the WCC Faith and Order Commission for honouring South Africa with your presence. It is a known fact that the ecumenical movement attends to many initiatives in Africa inter alia peace-making, negotiation and conflict resolution, reconciliation and justice. Thanks for being here.

Congratulations also to the Faculty of Theology for their centenary celebrations with the appropriate theme Gateway to the ... Yes, indeed, this Faculty is a gateway to the future. You closed the gates to a racial segregated past and are journeying jointly to an inclusive, egalitarian future. You are indeed a beacon of hope in South Africa. May the Lord bless the dean, Professor Buitendag, the academic staff, support staff and the students.

In a time when the demography of Christianity is changing, the importance of the WCC Faith and Order Commission meeting in South Africa cannot be underestimated. A century ago about two-thirds of the world's Christians lived in Europe. Today about one in every four Christians lives in sub-Saharan Africa (24\%). The share of the population that is Christian in sub-Saharan Africa climbed from 9\% in 1910 to $63 \%$ in 2010. We therefore thank you for taking this into account in your programmatic work and your theological reflection on new ecclesiologies. Your gathering here will not go unnoticed. Statements issued by the WCC in the past played a huge role in the theological discourse in global South, especially South Africa. For example, the WCC's Program to Combat Racism was wholeheartedly embraced by churches in South Africa and played a pivotal role in their struggle to dismantle apartheid and to declare the theological justification of apartheid a heresy. 
The Colloquium On Youth Day (16 June 2017) at the University of Pretoria, where in apartheid South Africa, only white people have access to, highlights our journey among others as a nation from a divided past to a joint future. The introduction of Afrikaans alongside English as a medium of instruction is considered the immediate cause of the Soweto uprising, but there are various factors behind the 1976 student unrest. These factors can certainly be traced back to the Bantu Education Act introduced by the Apartheid government in 1953 which was integrated into the Department of Native Affairs under Dr Hendrik F. Verwoerd. The provisions of the Bantu Education Act and some policy statements made by the Bantu Education Department were directly responsible for the uprisings. Dr Verwoerd, who engineered the Bantu Education Act, announced that 'Natives (blacks) must be taught from an early age that equality with Europeans (whites) is not for them'. ${ }^{1}$ Education in apartheid South Africa was unequal, inferior and racist. The protest started off peacefully in Soweto, but it turned violent when the police opened fire on unarmed students. By the third day, the unrest had gained momentum and spread to townships around Soweto and other parts of the country, for example to townships in the Cape Province. The University of the Western Cape (UWC) was an important site of student protest throughout the 1970s. Two months after the Soweto uprising in June 1976, on 02 August 1976, the UWC students convened a meeting to express solidarity with the students of Soweto and decided to embark on a boycott of classes. The massacre of innocent school children peaceably marching in Soweto in 1976 was seen by the students as an example of a gross violation of human rights involving education rights. The countrywide support for the student unrest cut across divisions of race, class and ethnicity.

Konrad Raiser, General Secretary of the WCC, once said reconciliation was once primarily the church's word, but today it is widely used by secular leaders who hope to establish peace in war-torn communities. In post-apartheid South Africa, we embarked as a nation on the Truth and Reconciliation process. Reconciliation has also to do with the uncovering of the truth and forgiveness. In the Truth and Reconciliation process in South Africa, both the victim and perpetrator revisited the divided past together and shared in collective feelings of hurt and shame. This is also the story of South Africa. The story of a people willing to embark on a pilgrimage of reconciliation and forgiveness. The premise of the Truth and Reconciliation process was that reconciliation is needed, not only at an individual level, nor only between individuals, but also within and between communities and the nation as a whole. Many victims justifiably insisted that they were not prepared to forgive if this meant that they must 'close the book on the past', 'let bygones be bygones' or 'forget about the past and focus on the future' (Truth and Reconciliation Commission of South Africa Report 1997:119). We as the people of South Africa realised that the road to reconciliation requires more than forgiveness and respectful remembrance. It requires more than kissing and hugging.
Forgiveness is not about forgetting, but rather means remembering the past in a way that makes a different kind of future possible for both victim and the wrongdoer (see Schreiter 2005:74-83; Vosloo 2013:2-11).

Reconciliation means peace with justice. Reconciliation, however, is an act of God and is never a human endeavour. According to Paul, it is God who takes the initiative towards reconciliation. 'In Christ God was reconciling the world to Godself' (2 Cor 5:19). Reconciliation is not about kissing and hugging each other, but it is an act of the living God. It is God at work bringing two unreconciled parties together. It is about the disruption and distortion of relationships and the restoration of relationship and reconciliation by the grace of God (sola gratia).

Africa struggled against all forms of domination, undermining, oppression, colonialism and imperialism. It is therefore a special honour as Africa President of the WCC to welcome you on the continent. Africa is being challenged among others by gender-based violence, femicide, incitement, atrocity crimes, war, statelessness, economic, social and political factors, the radicalisation of religion, and so on. This is the backdrop of your Faith and Order Commission Meeting in eMseni (place of grace). The African continent bears witness to the tragic consequences of the manipulation of religion to incite violence. Yet, it is also the home of untold instances of the power of religious leaders and actors to exert a positive influence. We welcome you therefore on the continent. May being here influence your theological deliberations and the embodiment of your reflections?

We are waiting with anticipation to the outcome of this consultation on New and emerging ways of being church and Ecclesiology from BEM to The Church: Towards a common vision and beyond. We are the people of the Way, ambassadors of the living God (2 Cor 5:17-21; Rom 3:21-30). May God grant you wisdom in your deliberations in responding to The church: Towards a common vision for our growth in fellowship and service to justice and peace.

\section{Gustav Claassen - greetings from the Dutch Reformed Church}

For the DRC, the centenary celebrations of the Faculty of Theology at the University of Pretoria, established in 1917, is a joyous event. The DRC has been one of the main role players in this faculty's history of 100 years since 1938.

The centenary celebrations offer the DRC a wonderful opportunity to remember the remarkable contributions the Faculty has made to the work and witness of the church in so many ways.

In true biblical way, our expectations of the years to come should contemplate the remarkable contributions of the past to give hope and perspective on the future. In this regard, it must be stated that the Faculty of Theology was prominent in 
every way in its creative engagement with life-giving theology and religious insight of service to academia, church and community.

From a DRC perspective, we want to express our heartfelt gratitude in the way the Faculty of Theology, from the outset, was to have a positive influence not only on the University of Pretoria, but also on the church and society. What come to mind is the monumental role it played in the forming of theologians, Bible translation, church leadership, research, community involvement and many other areas.

Regardless of how important the previous 100 years might have been, the emphasis of any centenary celebrations should be on the years to come. The vast contributions of the Faculty, over a broad spectrum in the past, make it possible to anticipate a prosperous and influential future in the following ways:

- providing relevant theological education

- nurturing transformative leaders

- groundbreaking research

- promoting justice and peace

- engaging with people on the margins of society.

May the Faculty always be an open gate, an invitation to enter, to meet one another and together to find the way of God. May the Faculty practice theology in such a way in the years to come that the love of God reaches all. The DRC would like to be part of this journey step by step for the years to come.

God bless the Faculty of Theology for the years to come!

\section{André G. Ungerer - Message to the Faith and Order Meeting on 16 June 2017}

The Nederduitsch Hervormde Kerk van Afrika (also known as the Netherdutch Reformed Church of Africa - NRCA or $\mathrm{NHK}$ ) and the DRC were founder members of the WCC in Amsterdam in 1948. Soon thereafter, the South African policy on apartheid became a problem for the WCC and the Second Assembly of the WCC in Evanston (1954) stated that any form of segregation based on race, colour or ethnic origin is contrary to the gospel, incompatible with the Christian view of what it means to be human, and with the nature of the church of Christ.

During a protest march on 21 March 1960, 69 people (10 of whom were children) were shot and killed and 180 (19 of whom were children) were wounded by the police. That event is known in history as the Sharpeville massacre. During the Cottesloe Consultation (December 1960), churches were asked to condemn Apartheid outright. The Afrikaans speaking churches were not prepared to do so. On 20 March 1961 at its General Assembly, the NHK passed a resolution to terminate their membership of the WCC.
On 31 May 1961, the Republic of South Africa was established, with apartheid as an official policy of the new republic. The NHK, in line with government policy, formulated Article III the controversial article in the NHK's Church Order - which regulated racially exclusive membership of the church and denounced interracial marriage. In 1982, NHK was suspended from the then World Alliance of Reformed Churches (today 'WCRC') by the General Council of WARC in Ottawa, and subsequently resigned. Since 1961, for 50 years, the NHK found itself in an ecumenical wilderness.

Article III was removed from the NHK Church Order in 1997. In 2010, the 69th General Assembly of the NHK passed Resolution 54 which states that Apartheid is contrary to the gospel of Jesus Christ because it is based on an idea of human irreconcilability, it sanctions injustice and damages the image of God in people. Although Resolution 54 was met with fierce resistance in the church, the extraordinary General Assembly of 2011 maintained the resolution. This marked the beginning of a painful church schism. Disputes over church buildings led to a process of litigation which, to this day, has not been resolved because of legal technicalities. But there is a ray of hope. There is the hope that exploratory conversations in the near future can lead to a satisfactory settlement. We pray that we can resolve this painful matter in a Christian manner without having to go to court.

After the General Assembly of 2010, the church applied for membership of the WCRC. The church was reinstated as a member in 2014 and a delegation of the church will attend the WCRC conference in Leipzig in June-July 2017.

There are still two outstanding issues. Firstly, to become an official member of the SACC. At this stage, we have observer status. I hope that further negotiations will lead to full membership. In my opinion, membership of the SACC is an imperative, especially because of the troubling times we are experiencing in this country. A united voice of South African churches is vital in an era when so many aspects of our Constitution are violated.

Membership of the All Africa Conference of Churches could be a next step. And, of course, full membership of the WCC. The Moderator of the church had the privilege of dining with Archpriest Dr Daniel Buda, WCC programme executive for Church and Ecumenical Relations, on 04 April 2017 at the Philadelphia congregation not far from here. Prof. Buda explained the conditions for becoming a member again. It was not possible to agree on a timeline yet, because the progress will depend on future resolutions of the General Assemblies of our church.

I sincerely pray that the NHK will attain full membership of the WCC in the near future. We will then have come full circle. A founding member that had become alienated from the other member churches, only to dwell in an ecumenical wilderness far too long, by the grace of God found its way back to rejoin the ecumenical family. That will indeed be a kairos event. 


\section{Acknowledgements} Competing interests

The authors declare that they have no financial or personal relationships which may have inappropriately influenced them in writing this article.

\section{Authors' contribution}

A.G.v.A. is the coordinating author; L.W.N. is the author of message of greetings on behalf of the University of Pretoria; J.B. is the author of welcoming word on behalf of the Faculty of Theology; O.F.T. is the author of the word of congratulations on behalf of the WCC; J.P. is the author of the message of greetings on behalf of the WCRC; M.A.P.v.H. is the author of the message of greetings on behalf of the WCC Africa; G.C. is the author of the word of congratulations on behalf of the DRC; A.U. is the author of message of greetings on behalf of the NRCA.

\section{References}

Corcoran, P.B. \& Osano, P.M., (eds.), 2009, Young people, education, and sustainable development: Exploring principles, perspectives, and praxis, Wageningen Academic Publishers, Wageningen.

Du Preez, M., 2016, 'Van Soweto tot \#RhodesMustFall', Beeld, 11 June, pp. 22-23.

Gwala, N., n.d., 'SABC Education - Poems for Youth Day', viewed 12 August 2017, from sabceducation.co.za/media-office/2090-poems-for-youth-day

Isaacs, L., 2016, 'Sharpeville massacre dark day in our history', Cape Times, 29 Apri 2016, viewed 12 August 2017, from https://www.pressreader.com/south-africa/ cape-times/20160429/282595967105063

Schreiter, R., 2005, 'Reconciliation and healing as a paradigm for mission', Internationa Review of Mission 94(372), 74-83. https://doi.org/10.1111/j.1758-6631.2005. tb00487.x

Truth and Reconciliation Commission of South Africa Report, 1997, viewed 12 August 2017, from www.justice.gov.za/trc/report/finalreport/Volume\%201.pdf

Van Aarde, A.G., 2017, 'Theologia and the ideologia of language, nation and gender - Gateway to the future from a deconstructed past', HTS Teologiese Studies/ Theological Studies 73(4), a4614. https://doi.org/10.4102/hts.v73i4.4614

Vosloo, R.R., 2013, 'Remembering the role of the Reformed Churches in the struggle for justice in South Africa (1960-1990): Some remarks on the promise and pitfalls of memory and historiography', Nederduitse Gereformeerde Teologiese Tydskrif 54(3\&4), 2-11.

World Council of Churches (WCC) [1983] 2016, "'Learning in Community": Sixth Assembly of the World Council of Churches, Vancouver, 1983', in M. Kinnamon (ed.), The ecumenical movement: An anthology of key texts and voices, 2nd edn. pp. 378-380, World Council of Churches, Geneva. 